\title{
Covid:19: Italy has wasted the sacrifices of the first wave, say experts
}

martapaterlini@gmail.com Cite this as: BMJ 2020;371:m4279 http://dx.doi.org/10.1136/bmj.m4279 Published: 12 November 2020

\section{The lessons of the first and harshest lockdown in Europe have not been heeded as Italy drowns in a second wave, writes Marta Paterlini}

\section{Marta Paterlini freelance journalist}

In October, Giulia Chiarcossi, 8o, called her doctor's office to arrange her flu vaccination, as she has done every year for the past 15 years, usually getting it done straightaway. "My family doctor told me to call back in November," she says, a little surprised. There were no flu vaccinations available.

Mindful of the dangers of winter and a potential twin epidemic of covid-19 and influenza, the Italian Ministry of Health has for months urged regions to start administering flu vaccinations early and extend free coverage to people over 60.

Chiarcossi lives in Brescia in the northern region of Lombardy, one of the epicentres of the first coronavirus wave, which began in February. Italy's most wealthy and populous region, Lombardy was until May the hardest hit region in the whole of Europe. $^{1}$

Yet despite this, and the ministry's plea, Lombardy's regional government did not place its vaccine orders until September and started vaccinating only in mid-October. Some people have received flu vaccinations, but Chiarcossi is one of many who must wait until an unspecified date in November.

More than one million Italians have been infected with covid-19 to date. "Now, again, it seems that Italy is trying to chase the virus instead of containing [it]," says Alberto Mantovani, scientific director of the Humanitas Research Hospital in Milan. "We are paying for a structural failure of our primary care.”

\section{Human capital}

The pandemic has revealed the strengths and weaknesses of Italy's region based healthcare system. Although the Ministry of Health has been ultimately responsible for the administration of healthcare since 1992, much of the control has been gradually decentralised and passed to its 20 regions.

This has led to disparities in the organisation of health services. Some regions, such as Veneto (Venice), Toscana (Florence), and Emilia Romagna (Bologna) were better equipped for a pandemic, with a healthcare policy that emphasises decentralised primary care, a network of GPs, and home visits.

In contrast, other regions, most notably wealthy Lombardy, placed an emphasis on large, urban hospitals both public and private, focusing on surgical and specialty care. That system backfired in the pandemic, funnelling sick people into the hospitals, which in turn became sources of infection.

GPs around the country have been inundated with phone calls about covid-19 as coronavirus testing hubs report long queues requiring up to 10-12 hours of waiting in some poorer southern regions. Italy has 71.1 GPs per 100 ooo people-42987 in total compared with 47148 in 2000. ${ }^{2}$ Because of the paucity of GPs available, people visit the emergency departments, risking further outbreaks inside hospitals.

Mantovani says there is a "lack of human capital in all the gears of the healthcare system," which was dangerously exposed by the pandemic.

\section{Relaunch decree}

In May the government signed the relaunch decree, allocating $€_{3.25 \mathrm{bn}}(£ 2.93 \mathrm{bn}$; \$3.83bn) to reboot the country's public health system. Around $€ 1 \mathrm{bn}$ is earmarked for "territorial assistance"-that is, boosting local healthcare such as GPs and health centres, as well as emergency medical services.

Almost $€$ 1.5bn will be spent upgrading the hospital network. The decree will increase the number of intensive care beds by 3500 to a total of 8679 (similar to England's capacity). ${ }^{3}$ As of 9 October, 1279 beds had been added, with an uneven geographical distribution.

The purchase of respirators and ventilators for intensive care units has also been delayed, but the major problem is the shortage of professionals to operate them.

Carlo Palermo, president of Anaoo, the biggest trade union for doctors in the country, has said there is also a shortage of anaesthetists, which he blames on "known errors in the planning of specializations at the university training a decade ago.” Almost 2000 anaesthetists are needed to manage the increase in new patient capacity, not to mention the nurses and other specialists required for the plan to enhance subintensive care, said Palermo in a statement.

According to Nicola Latronico, head of anaesthesia and critical care at Brescia Hospital (Spedali Civili di Brescia), the recruitment promised in the decree has been slow because the process cannot be rushed. Not all applicants have the required skill set for certain specialties, and training has also been paused since the first wave of the pandemic.

Latronico says the situation in Lombardy's intensive care units is currently stable, but after the emergency covid hubs were put on standby during the summer drop in caseloads, a now rapidly rising infection rate has seen the hubs reopen. Covid patients currently occupy $30 \%$ of intensive care units and the number is growing, he says.

"We know how to handle the treatments much better than [in] March," he says. "However, this time we should guarantee the care for all other pathologies, 
and, unfortunately, we must reduce some surgeries and convert the personnel to covid wards."

\section{Failure to learn}

Lombardy is registering close to 7558 new covid-19 infections in a single day, breaking records set during the peak of the first wave. According to the Istituto Superiore di Sanità, the leading scientific technical body of the Italian National Health Service, this trend is emerging nationwide, with a national $\mathrm{R}$ number close to two, over 35908 infections a day, and around 580 deaths.

On 22 October, authorities in the Lombardy, Lazio (Rome), and Campania (Naples) regions voluntarily imposed their own curfew from 11 pm until 5 am and closed secondary schools to physical attendance. Three days later, Prime Minister Giuseppe Conte announced separate, stricter measures nationwide, closing gyms and swimming pools and forcing bars and restaurants to shut at 6 $\mathrm{pm}$. Yet more restrictions began on 6 November lasting until at least 3 December, which involve a three tiered system depending on $\mathrm{R}$ number and intensive care unit capacity. Lombardy, Piedmont, Aosta Valley in the north, and Calabria in the south were all classified as the highest "red" tier and put into lockdown, despite fierce debate with the regional governors fearing the economic effects of another shutdown. A curfew of $10 \mathrm{pm}$ has now been implemented nationwide, and more regions might become red, but it is not clear which ones yet.

However, many experts think all this should have started earlier, with the mix of measures showing a lack of strategy. "In March we were the first in Europe and the other countries did not take us seriously," says Mantovani, "I think that some European countries have a huge responsibility in not having learnt the lesson from the March outbreak in Lombardy. Now we are repeating the same mistakes."

In a statement to The BMJ, the Ministry of Health said a strategy has been in place since September, devised by the Istituto Superiore di Sanità, the Ministry of Health, and the regional governments together. It outlines four different epidemiological scenarios, identifying for each the associated risks and the measures necessary to mitigate the curve of contagion. The ministry said that "between the ministry and the regions there is a continuous and fluid dialogue which has not been interrupted."

Still, Mantovani thinks that Italy did not work on preparedness fast enough and did not take note of the data when it should and could have done. "There was no respect for the data and the simple message, 'Our actions are the virus' did not get through.” He blames the poor and misleading communication of some authorities, the media, and some academics for confusing the public and health officials.

What worries him is that with renewed restrictions and lockdowns, the care of other pathologies are at risk again. In the first wave lockdown, patients had to miss 1.5 million examinations for non-covid conditions, including about $50 \%$ of all oncological screenings.

\section{Test and trace}

Nino Cartabellotta, founder of the Gimbe Foundation, a non-profit organisation working on healthcare issues, flagged the increase in infections at the end of the summer with regular press releases. Cartabellotta claims that the country needed courageous and prompt action much earlier. From having only 1400 cases a week, Italy saw the numbers rise and then increase exponentially, and now it is in trouble. "Over [the] summer everybody relaxed and then we witnessed the failure to upgrade public transport and from the health point of view, the Achilles' heel was the testing and tracing system," he says.

Italy's first outbreak in the Veneto region was confined to a small village near Padua with 3000 inhabitants. Andrea Crisanti, a virologist at Italy's Padua University and Imperial College London, led a study of this area in March, testing almost everyone in the quarantined village. ${ }^{4}$ The virus was well contained in Veneto and $40 \%$ of cases showed no symptoms-one of the first suggestions that asymptomatic cases are important in the spread of the pandemic.

After quarantine, another round of mass testing in the village showed that the infection dropped from nearly $3 \%$ to $0.4 \%$. Crisanti's team had produced evidence that mass testing combined with contact tracing, case isolation, and community lockdowns can stop local outbreaks swiftly.

At the end of August, he proposed to the Ministry of Health a national surveillance plan with at least 300000 to 400000 swab tests a day, expecting the cost to be an initial €4om. "At the time there were very few positive cases. Now, it is no longer possible to isolate the small outbreaks and Italy is back to the starting point," he says, adding that the Italian contact tracing system "crumbled" at the beginning of October.

Antonio Russo, an epidemiologist at the Agenzia di Tutela della Salute, which manages the testing and tracing in Milan and its province, told The BMJ: "We have been testing 10000 people per day (both with and without symptoms) for 3.5 million inhabitants. However, now the volume is too much and we are no longer able to carry out epidemiological interviews in a timely way and face a delay of two weeks with the response.”

In the first week of October, the Lazio region asked its GPs and paediatricians to help administer rapid swab tests for covid-19, a task not in their job descriptions. In a public statement to the media, Italy's biggest GP union, the Federation of General Practitioners, said that its members cannot offer such a service without precise rules and guarantees around personal protective equipment for them and their patients.

Some doctor associations continue to protest, but by 28 October, the federation had signed an agreement with the Ministry of Health to offer the swab tests nationally, with the health minister announcing $€ 30 b n$ to fund the initiative. The question is, will it work and will it work fast enough to counter the virus's resurgence?

\section{Commissioning and peer review: Commissioned; not peer reviewed.}

Competing interests: I have read and understood the BMJ policy on declaration of interests and have no relevant interests to declare.

Paterlini M. On the front lines of coronavirus: the Italian response to covid-19. BMJ 2020;368:m1065. doi: 10.1136/bmj.m1065 pmid: 32179517

2 Statistica. General practitioner employees in Italy 2000-2019. Statistica 2020;22. https://www.statista.com/statistics/462201/general-practitioners-employment-in-italy.

3 NHS. Statistical press notice. Monthly critical care beds and cancelled urgent operations (MISITREP) data, England. Feb 2020. https://www.england.nhs.uk/statistics/wp-content/uploads/sites/2/2020/04/MSitRep-SPN-FEBRUARY-2020-auY71.pdf

4 Lavezzo E, Franchin E, Cristanti A. Suppression of a SARS-CoV-2 outbreak in the Italian municipality of Vo'. Nature2020;584:425-9. doi: 10.1038/s41586-020-2488-1. pmid: 32604404

This article is made freely available for use in accordance with BMJ's website terms and conditions for the duration of the covid-19 pandemic or until otherwise determined by BMJ. You may use download and print the article for any lawful, non-commercial purpose (including text and data mining) provided that all copyright notices and trade marks are retained. 